\title{
MULTIPLE DENDROCHRONOLOGICAL SIGNALS INDICATE THE ERUPTION OF PARÍCUTIN VOLCANO, MICHOACÁN, MEXICO
}

\author{
PAUL R. SHEPPARD ${ }^{1 *}$, MICHAEL H. ORT ${ }^{2}$, KIRK C. ANDERSON ${ }^{3}$, MARK D. ELSON ${ }^{4}$, \\ LORENZO VÁZQUEZ-SELEM ${ }^{5}$, ANGELIKA W. CLEMENS ${ }^{1}$, NICOLE C. LITTLE ${ }^{6}$, and ROBERT J. SPEAKMAN ${ }^{6}$ \\ ${ }^{1}$ Laboratory of Tree-Ring Research, University of Arizona, Tucson, AZ 85721, USA \\ ${ }^{2}$ Departments of Environmental Sciences and Geology, Box 4099, Northern Arizona University, Flagstaff, AZ 86011, USA \\ ${ }^{3}$ Bilby Research Center, Northern Arizona University, Box 6013, Flagstaff, AZ 86011, USA \\ ${ }^{4}$ Desert Archaeology, Inc., 3975 N. Tucson Blvd., Tucson, AZ 85716, USA \\ ${ }^{5}$ Instituto de Geografía, Universidad Nacional Autónoma de México, Ciudad Universitaria, 04510 México D.F., MÉXICO \\ ${ }^{6}$ Museum Conservation Institute, Smithsonian Institution, Suitland, MD 20746, USA
}

\begin{abstract}
The eruption of Parícutin (1943-1952), a cinder cone volcano in Michoacán, Mexico, caused dendrochronological and dendrochemical responses that might be useful as general dating tools for eruptions. For the eruption period, pines near Parícutin have slightly suppressed ring widths plus high inter-annual variability of width. Wood anatomy changes include traumatic resin ducts and thin bands of false latewood. Dendrochemistry of tree rings shows little temporal variation in most elements, but beginning in 1943 sulfur content increased in rings of four trees and phosphorus content increased in rings of two trees. Hypotheses for increased $\mathrm{S}$ and $\mathrm{P}$ include new availability of pre-existing soil $\mathrm{S}$ and $\mathrm{P}$ and/or new input of $\mathrm{S}$ and $\mathrm{P}$ from the tephra itself. Pines at Parícutin also show suppressed ring widths for five years beginning in 1970, and had the eruption date not been known, the most likely conclusion from ring-width data alone would have been an eruption from 1970 to 1974 . However, the 1970s suppression was in response to defoliation by a pine sawfly outbreak, not an eruption. For dendrochronological dating of cinder-cone eruptions, a combination of multiple characteristics (width, chemistry, and anatomy) would be more reliable than depending on any one characteristic alone.
\end{abstract}

Keywords: Parícutin volcano, dendrochronology, dendrochemistry, sulfur, phosphorus.

\section{INTRODUCTION}

Dating of volcanic eruptions of the last few thousand years can have error on the order of 100 years (Noller et al. 2000). Tree-ring dating can serve well in such cases, as its precision is on the order of one year. However, interpreting ringwidth changes as evidence of an eruption is not necessarily straightforward because other forest disturbance events such as drought, fire, or insect infestation can cause similar ring-width changes (Sheppard et al. 2005). In this research, the eruption of Parícutin, a cinder cone in Mexico, was investigated for multiple dendrochronological

\footnotetext{
* Corresponding author: sheppard@1trr.arizona.edu; Fax 520-621-8229; Telephone 520-621-6474
}

changes, including tree-ring chemistry, which might be useful for dating eruptions.

Located in the Trans-Mexican Volcanic Belt (Figure 1A) of west-central Michoacán (Figure 1B), Parícutin $\left(19^{\circ} 30^{\prime} \mathrm{N}, 102^{\circ} 15^{\prime} \mathrm{W}, 2,700 \mathrm{~m}\right.$ a.s.1.) erupted between 1943 and 1952. The eruption formed a 424-m-high cinder cone, and it covered an area of $24.8 \mathrm{~km}^{2}$ with $0.7 \mathrm{~km}^{3}$ of lava and an area of $300 \mathrm{~km}^{2}$ with $>15 \mathrm{~cm}$ of tephra (Luhr and Simkin 1993). Tephra fall was heaviest between 1943 and 1945, with half of the tephra of the eruption ejected during the first year (Eggler 1967). Trees within $2 \mathrm{~km}$ of the cinder cone were killed (Trask 1943; Eggler 1948), but more-distant trees survived the eruption with varying effects. Because the timing of the eruption 


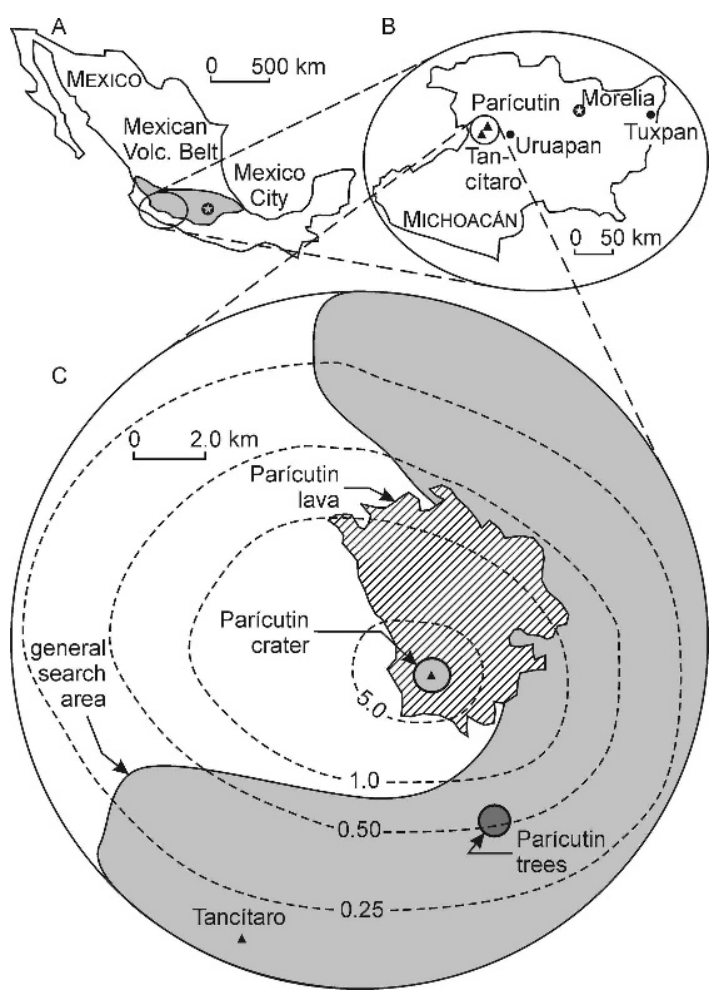

Figure 1. Map of Mexico showing the Trans-Mexican Volcanic Belt (A), map of Michoacán (B), and map of Parícutin tephra fall depths (Segerstrom 1950) (C). Tephra fall isopach contours (dashed-line circles) in $\mathrm{C}$ are in meters and are original depths, i.e. before settling and compaction. Eruption response trees reported here were growing south-southeast of Parícutin (C), and control trees were growing near the town of Tuxpan (B).

is known, Parícutin can serve as a case study for determining ring-width and dendrochemical responses to cinder-cone eruptions.

Although cinder cones are the most abundant volcanic landform on Earth (Wood 1980), they have not been a focus of dendrovolcanological research. Tree scarring and altered ring-width growth are documented for stratovolcano and shield volcano eruptions (Yamaguchi and Lawrence 1993; Pelfini and Gorza 1994; Biondi et al. 2003), but little research has been published on tree-ring responses to cinder-cone eruptions (Finch 1937; Eggler 1967).

In addition to ring-width changes, elemental concentrations in tree rings might also reflect environmental changes brought about by an eruption (Hughes 1988). Dendrochemistry, the measurement and interpretation of elemental concentrations in tree rings (Smith and Shortle 1996), has been applied in a wide array of environmental research, including to hemisphericand global-scale explosive eruptions (Hall et al. 1990; Padilla and Anderson 2002; Ünlü et al. 2005; Pearson 2006; Pearson et al. 2005, 2006). However, we know of no dendrochemistry research on cinder-cone eruptions. Cinder-cone volcanism, in which a volcano forms in a single discrete event, is ideal for investigating tree-ring responses to eruptions, as only one event need be identified in the record. Given that cinder-cone tephra can change soil nutrient and elemental availability in various ways, and that trees can record environmental chemical changes in their growth rings, dendrochemistry of tree rings affected by tephra might be an independent indicator of cinder-cone eruptions. Dendrochemistry might be particularly useful in dating eruptions where ring-width signals are either weak or ambiguous. The objective of this research is to search for and document multiple tree-ring responses to the eruption of Parícutin that might then be useful for dating cinder-cone eruptions generally.

\section{METHODS}

The Parícutin region is covered in Quaternary basalt and basaltic andesite underlain by Tertiary andesite (Williams 1945). Parent material for soils are late Pleistocene and Holocene basalt and basaltic andesite as lava flows and pyroclastic deposits and as redeposited volcaniclastic material in alluvial plains (Siebe et al. 2003). Pre-eruption soils are Andisols, whereas soils formed in cinders are either Entisols or, where re-deposited, Fluvents (Siebe et al. 2003). Pre-eruption Andisols contain abundant allophane, an amorphous hydrous aluminosilicate formed by the weathering of volcanic material (van Olphen 1971).

Although the suitability of tree species for dendrochemistry should be considered in planning dendrochemical research (Cutter and Guyette 1993), the most practical determinant of which species to sample is what species actually grows at the site of interest (Watmough 1997). Within the tephra fall of Parícutin, vegetation is pine forest 
with two principal species (Pinus leiophylla and $P$. pseudostrobus) and two minor species (P. montezumae and P. teocote) (Farjon and Styles 1997). Ecologically, these pines are similar to one another (Eggler 1948) and are hereafter grouped together in this research. Most large pines around Parícutin have vertical scars extending from the ground to as high as $2 \mathrm{~m}$ from resin tapping (Pulido and Bocco 2003), and although it is preferable in dendrochemistry to avoid trees that are physically injured (Smith and Shortle 1996), sampling resintapped trees was inevitable in this research. Resin tapping does not appear to have unduly stunted tree growth as tapped trees typically have full crowns and high radial growth rates. If resin tapping caused changes in elemental concentrations of tree rings, those changes would not be synchronous across multiple trees and therefore should not constitute a replicated dendrochemical signal of environmental change.

A search for old pines was conducted in areas with 10-75-cm depth of tephra fall (Segerstrom 1950) in a broad swath north, east, south, and southwest of Parícutin (Figure 1C). Most pines at Parícutin are not old enough to overlap with the eruption in spite of their being up to $1 \mathrm{~m}$ in diameter at ground level. Forest productivity in the area is high (Eggler 1948; INEGI 1997), caused in part by a temperate $\left(10^{\circ} \mathrm{C}\right.$ average annual temperature) and humid (almost 2,000 mm total annual precipitation with the rainfall peak during summer) climate that is highly favorable for tree growth (Inbar et al. 1994). Consequently, radial growth of these pines is often $>1 \mathrm{~cm}$ per year, especially during early years in tree life. The forest is also managed commercially for timber. Even with extensive searching in the field, only four pines were found with at least several rings predating the eruption. These trees were located about $4 \mathrm{~km}$ south-southeast of the crater (Figure 1C). Although more sample trees would have been preferable, four trees allow for at least the possibility of evaluating inter-tree variability in response to the eruption.

For control comparison purposes (Forget and Zayed 1995), a pine forest was sampled in eastern Michoacán (near Tuxpan, $19^{\circ} 34^{\prime} \mathrm{N}$, $100^{\circ} 28^{\prime} \mathrm{W}, 2,000 \mathrm{~m}$ a.s.1., Figure 1B). At more than $200 \mathrm{~km}$ from Parícutin, Tuxpan is well outside the zone of tephra fall of the eruption (Eggler 1945). At Tuxpan, trees of $P$. oocarpa (Farjon and Styles 1997) were found to be old enough to predate the eruption of Parícutin and were therefore sampled.

Core samples of radial growth were collected from living trees using standard tree increment borers cleaned between trees with isopropyl alcohol, and larger blocks of wood were collected from stumps using a chain saw. In most cases, only one sample was collected per tree in order to maximize the number of trees sampled while accepting that dendrochemical variability is smaller within trees than between trees (McClenahen et al. 1989). Increment cores were not glued into mounts, but rather they were prepared for analysis using a pinch clamp (Phipps 1985). Tree samples were sanded to expose finely polished transverse views of growth rings. Ring growth was crossdated (Douglass 1941) with emphasis on identifying anatomical anomalies during the eruption period of 1943-1952. Tuxpan trees could not be crossdated per se, as ring growth there was too complacent to identify distinctive patterns and/or did not show common patterns across trees. However, Tuxpan tree rings were confidently identifiable based on wood anatomical characteristics (Kramer and Kozlowski 1979) and were counted back in time from the bark. Two Tuxpan trees were measured for comparison to Parícutin trees.

For tree-ring samples that were old enough to have pre-eruption rings, the sanded surface was removed using stainless steel razor blades to eliminate sanding as a source of cross-ring contamination (Pearson et al. 2005). Rings were separated for dendrochemical measurements using a stainless steel chisel. For dendrochemical analysis of Tuxpan trees, samples were separated into 5-ring groups counting back in time from the bark.

Wood samples were freeze-dried to a constant weight and then weighed into precleaned, pre-weighed, trace-metal-free polypropylene centrifuge tubes. For every $25 \mathrm{mg}$ of sample, $1 \mathrm{~mL}$ of concentrated Fisher brand Optima grade nitric acid $\left(\mathrm{HNO}_{3}\right)$ was added to the tube. The samples 
remained in the acid at room temperature for 2 3 days, and the solutions were then heated to $70^{\circ} \mathrm{C}$ in an ultrasonic bath for 3 hours to complete the digestion.

Following digestion, the sample tubes were reweighed to calculate exact dilution factors. After thorough mixing, aliquots (approximately $0.25 \mathrm{~g}$ ) of the digestates were taken and gravimetrically diluted by a factor of approximately 20 with ultrapure $18.2 \mathrm{M} \Omega$-cm water and spiked with internal standards (Sc and In).

For the trace-metal measurements, the samples were analyzed using a VG Axiom magneticsector inductively coupled plasma mass spectrometer, which is capable of resolving most interferences caused by molecular ions that pose problems for quadrupole ICP-MS instruments. Solutions were measured for $\mathrm{B}, \mathrm{Na}, \mathrm{Mg}, \mathrm{Al}, \mathrm{P}, \mathrm{S}, \mathrm{K}, \mathrm{Ca}, \mathrm{Ti}$, $\mathrm{V}, \mathrm{Cr}, \mathrm{Mn}, \mathrm{Fe}, \mathrm{Co}, \mathrm{Ni}, \mathrm{Cu}, \mathrm{Zn}, \mathrm{Rb}, \mathrm{Sr}, \mathrm{Ag}, \mathrm{Ba}$, $\mathrm{La}, \mathrm{Eu}, \mathrm{Ta}$, and $\mathrm{Pb}$. The resulting data were calibrated using a series of linearity standards prepared from multi-element calibration standards obtained from High Purity Standards. Sc and In internal standards were added to the linearity standards. Five standard points were used to calibrate the instrument for all elements of interest. Concentrations for all standards were calculated and these data were used to create the linear calibration curve of instrument response versus concentration (for each analyte).

Some of the measured elements are major components in volcanic rocks, including the Parícutin tephra (Wilcox 1954), or plant macronutrients (Kramer and Kozlowski 1979). Other elements on this list have no known direct connection with volcanoes or plant nutrition but were measured in order to provide a background pattern of temporal variability unrelated to the eruption (Hall et al. 1990). Limits of detection were all $\leq 200 \mathrm{ppb}$, with many elements having a limit of detection $\leq 10 \mathrm{ppb}$.

\section{RESULTS}

\section{Ring-Width Responses to the Eruption}

Various ring-width responses to the eruption are evident. In one notable example (Tree PAA02A), ring widths of the eruption period are
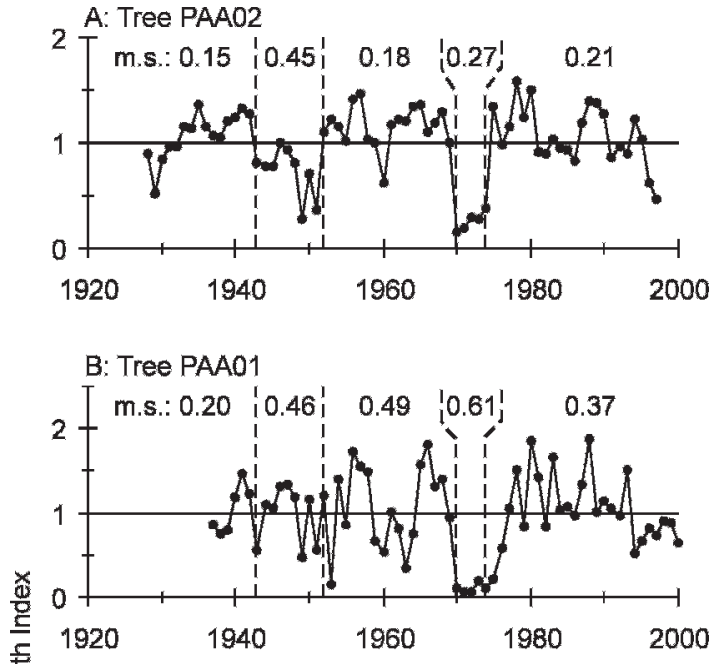

C: Tree PAA11
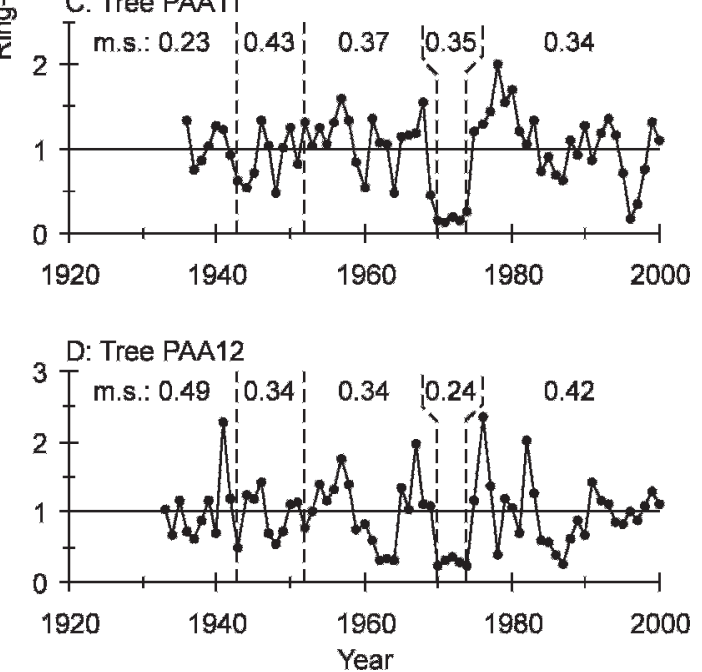

Figure 2. Standardized ring-width index series for all four Parícutin trees. Ring widths were measured to $\pm 0.01 \mathrm{~mm}$ using a typical tree-ring increment measuring system. Individual index series were created by dividing ring-width series by 40 -year spline curves (Cook and Peters 1981). Vertical dashed lines mark the eruption and defoliation periods. The m.s. values are the mean sensitivity values for each period separated by the vertical dashed lines.

narrow and inter-annual variability in ring width is high as indicated by more than a doubling of mean sensitivity (absolute difference of two consecutive rings divided by their average; Fritts 1976) (Figure 2A). Similar ring-width characteristics have been reported previously at Parícutin (Eggler 1967), but the other three trees in this 


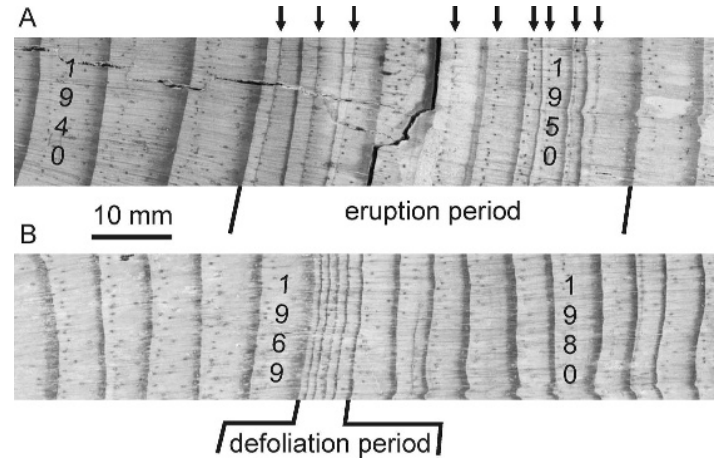

Figure 3. Growth rings of Parícutin Tree PAA02, which grew within the tephra fall zone of Parícutin, showing the eruption period (A) and the defoliation period (B). Ring growth is from left to right. Two rings on each image are marked with their year date of formation for time reference. Arrows in A point to aligned resin ducts and/or false latewood in rings of the eruption period.

study do not show strong ring-width responses to the eruption (Figure 2B-D).

Additionally, within rings of Tree PAA02A during the eruption period, resin ducts are aligned along with latewood-like tracheids to form what appear to be thin, false-ring bands (Figure 3A). In non-eruption rings, resin ducts occur more randomly and false-ring latewood cells are not as evident. Traumatic resin ducts in growth rings are a response to physical disturbance to trees (Wimmer et al. 1999), but false rings are more typically associated with climatic phenomena such as late spring drought (Wimmer 2002). Again, the other three trees in this study do not show strong ring anatomical responses to the eruption.

\section{Dendrochemical Responses to the Eruption}

Most of the elements measured in Parícutin tree rings show little temporal variation, thereby establishing a background pattern of no particular variability related to the eruption. By contrast, ring sulfur content shows a pattern that is probably related to the eruption. Pre-eruption ring $\mathrm{S}$ contents of $50-100 \mathrm{ppm}$ conform to typical literature values for wood (Tendel and Wolf 1988; Häsänen and Huttunen 1989), but then ring S increases by varying amounts beginning in 1943 . Relative sizes of these increases range from $1.2 \times$ to $4.3 \times$ higher (Figure $4 \mathrm{~A}-\mathrm{D}$ ). Ring $\mathrm{S}$ remains elevated after the eruption, making this a longterm change. By comparison, in Tuxpan trees ring $\mathrm{S}$ shows no abrupt changes (Figure 4E-F), and relative variability before and after 1943 in ring $\mathrm{S}$ is near $1.0 \times$ (no change).

Ring phosphorus also shows a pattern that is probably related to the eruption. Pre-eruption ring $\mathrm{P}$ contents of 3-25 ppm are within the expected range for wood (Tendel and Wolf 1988; Häsänen and Huttunen 1989), but then ring $P$ increases by varying amounts beginning in 1943. Relative sizes of these increases are strong within two trees $(1.4 \times$ and $6.0 \times$ higher, Figure $4 \mathrm{~A}-\mathrm{B}$ ) but weak in two other trees (no change, Figure 4C-D). In the trees where ring $\mathrm{P}$ increased, ring $\mathrm{P}$ remains elevated after the eruption, making this a long-term change. In Tuxpan trees, relative variability before and after 1943 in ring $\mathrm{P}$ of Tuxpan trees is inconsistent, with one tree showing no change (near $1.0 \times$, Figure 4E) but the other one showing an increase (1.6× higher, Figure 4F). Neither of these changes in ring $\mathrm{P}$ at 1943 in Tuxpan trees is statistically significant. The trees showing the strongest ring $\mathrm{P}$ response (PAA02 and PAA01) are located on a flat alluvial plain where redeposition of subsoils has occurred, whereas trees showing weak or no ring P response (PAA11 and PAA12) are located on steep hillslopes where redeposition of subsoils is not likely.

Ring $\mathrm{S}$ and $\mathrm{P}$ covary through time. This phenomenon occurs in Parícutin trees as well as in trees of Tuxpan (Figure 4). The increases in $\mathrm{S}$ and $\mathrm{P}$ in recent rings of all trees are probably artifacts of the tree physiological phenomenon of accumulating essential nutrients in outermost rings. Variation of $\mathrm{S}$ and $\mathrm{P}$ does not reflect annual precipitation, which was not unusual during the eruption period nor has it increased steadily through time (Figure 5).

\section{Ring-Growth Changes During 1970 to 1974}

All four old pines at Parícutin show decreased ring widths during the early 1970s (Figure 2), as do most other sampled pines that are old enough to predate the 1970s (Figure 6). This ring-width suppression is more severe than that caused by the 1943-1952 eruption. Interan- 


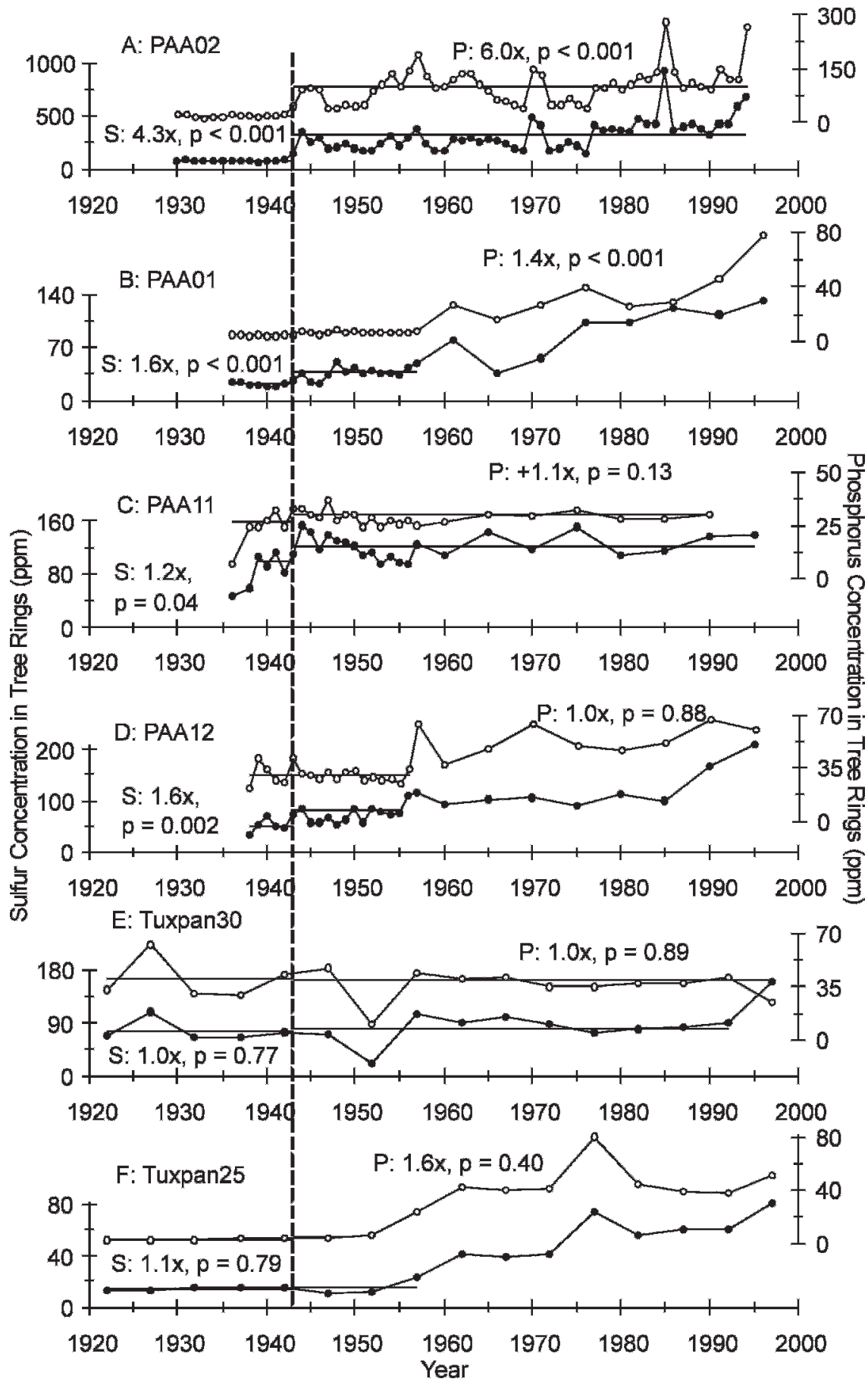

Figure 4. Dendrochemical concentrations for sulfur (lines with solid circles corresponding to the left-side y-axes) and phosphorus (lines with open dots corresponding to the right-side y-axes) for four Parícutin trees (A-D) and two control Tuxpan trees (E-F). The vertical dashed line denotes 1943, the first year of the eruption of Parícutin. Horizontal solid lines represent pre- or post-eruption means of S and P. Relative changes in S and P at 1943 are given along with p-values of significance based on t-tests of means (Sokal and Rohlf, 1981). 


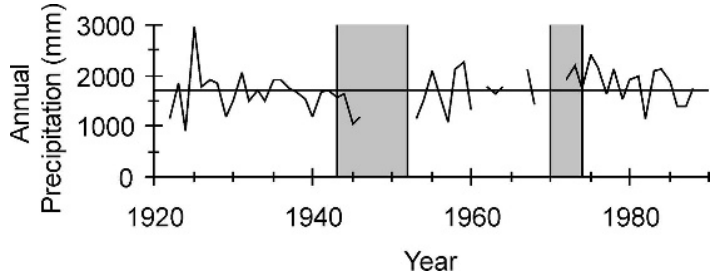

Figure 5. Annual precipitation at Uruapan, Michoacán $\left(19^{\circ} 25^{\prime} \mathrm{N}, 102^{\circ} 04^{\prime} \mathrm{W}, 1650 \mathrm{~m}\right.$ a.s.l., Figure 1$)$. Horizontal line is the series average, and shaded boxes mark the periods of the eruption (1943-1952) and the defoliation (1970-1974).

nual variability in ring width during the 1970s is inconsistent, being high in one tree (Figure 2B), low in another (Figure 2D), and unchanged in others (Figure 2A, C). The 1970s rings also do not include traumatic resin ducts or false rings (Figure 3B). Considered together, these ring-width features of the 1970s are distinct from those of the eruption period. The 1970s ring-width suppression is probably in response to defoliation by a primitive wasp species called pine sawfly (Zadiprion sp., Hymenoptera: Diprionidae), which experienced an outbreak throughout the area in the early 1970s (Méndez and Tovar 1985; Tovar et al. 1995). Dendrochemically, ring $S$ and $P$ are high for 1970 and 1971 in one tree (PAA02, Figure 4A), but then they return to pre-1970 values. Temporary spikes in ring elements during defoliation events could be caused by brief changes in soil nutrient cycling from deposition of feces of the insects (Hunter et al. 2003). Variation in $\mathrm{S}$ and $\mathrm{P}$ during the 1970s does not reflect annual precipitation, which was not unusual during the defoliation period (Figure 5). In any case, these shortlived spikes in ring $\mathrm{S}$ and $\mathrm{P}$ during the insect outbreak differ markedly from the long-term increases during and after the eruption.

\section{DISCUSSION}

\section{General Dendrochemistry}

Dendrochemistry has had mixed success in relating temporal variability in tree-ring concentrations of elements to changes in environmental availability of those elements (Hagemeyer 1993). On the positive side, many studies have interpreted

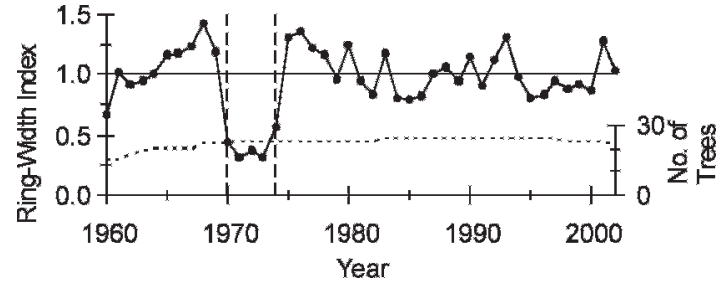

Figure 6. Average ring-width index chronology since 1960 from sampled Parícutin trees old enough to predate 1970. Ring widths were measured and indexed the same as for Figure 2. Vertical dashed lines indicate the defoliation period, and the dotted line indicates sample depth.

variations in dendrochemical concentrations as evidence of environmental change through time (e.g. Baes and McLaughlin 1984; Momoshima and Bondietti 1990; Guyette and Cutter 1994; Yanosky and Kappel 1997; Orlandi et al. 2002). On the negative side, other studies have concluded that such an interpretation was not possible (e.g. DeWalle et al. 1999; Bindler et al. 2004). In negative cases, variation in dendrochemical concentrations has been ascribed to differences in tissues at the boundary of heartwood (rings around the tree pith) and sapwood (rings closer to the bark) (Brownridge 1984), to elements accumulating in outermost rings (Poulson et al. 1995), or to broad temporal smoothing of elemental concentrations from the sap stream coursing through many growth rings as opposed to just the ring of the current year (Hagemeyer et al. 1992).

Given such mixed success across different studies, it is necessary to evaluate each use of dendrochemistry on its own merits. In this use of dendrochemistry at Parícutin:

1. Heartwood-sapwood boundaries of old pines at Parícutin typically post-date 1943, so this physiological phenomenon does not overlap with the eruption and therefore should not be an issue for dating the eruption.

2. Concentrations of $\mathbf{S}$ and $\mathbf{P}$ are elevated in outermost rings of trees, probably as a result of conserving essential nutrients in tissues that are active physiologically (Smith and Shortle 1996). If recent environmental changes in $S$ or $\mathrm{P}$ have taken place in Parícutin forests, dendrochemical signals of those changes could 
be interfered with, if not masked entirely, by physiological conservation of $\mathrm{S}$ and $\mathrm{P}$ in young wood tissue. However, the eruption began over 60 years ago, which appears to be far enough back in time to avoid the physiological effect of the outermost rings. Concentrations of $\mathrm{S}$ and $\mathrm{P}$ in pre-1950 rings are reasonable in magnitude. Therefore, trees that are old enough to predate the eruption should at least be eligible to display dendrochemical responses of $\mathrm{S}$ and $\mathrm{P}$ without being affected by high values that are not related to environmental availability.

3. Ring $\mathrm{S}$ and $\mathrm{P}$ show annual variability throughout the time span of the trees, including abrupt and sizeable changes. If broad temporal smoothing were occurring, annual variability would not be so evident. Therefore, broad temporal smoothing does not appear to be a factor for ring $\mathrm{S}$ and $\mathrm{P}$ at Parícutin.

Accordingly, the increase in ring S at 1943 in Parícutin trees can be interpreted as evidence of the eruption, especially when compared to Tuxpan trees showing no change in ring $\mathrm{S}$ at that time. Realistically, the timing of this increase in ring $\mathrm{S}$ at the start of the eruption is not likely to have occurred by mere coincidence, and the replication of this increase in ring $\mathrm{S}$ across multiple trees qualifies this dendrochemical pattern as a signal from the known eruption. The 1943 increase in ring $\mathrm{P}$ occurs in some but not all Parícutin trees, making this pattern more difficult to discern from Tuxpan trees. For the trees with a ring $\mathrm{P}$ response, the timing of the increase at the start of the eruption probably could not have occurred by mere coincidence. Ring P can be interpreted as a potential indicator of the eruption, but it is less consistent across trees.

These ring $\mathrm{S}$ and $\mathrm{P}$ signals at Parícutin match similar results found in trees near Cinder Cone of Mt. Lassen, California. That cinder cone has been dated to the late $1600 \mathrm{~s} \pm 40$ years using radiocarbon, paleomagnetism, and ring-width dendrochronology (Clynne et al. 2000), and dendrochemical increases in $\mathrm{S}$ and $\mathrm{P}$ in some trees beginning in 1666 confirm that dating (Sheppard et al. in review).

\section{Inter-tree Variability}

The question arises: why are responses in ring width, ring $\mathrm{S}$, and especially $\mathrm{P}$, to Parícutin not more consistent across different trees? For example, dendrochronological and dendrochemical responses are strong in Tree PAA02 but weaker in other trees. Similar inter-tree variability was found at Cinder Cone of Mt. Lassen, California (Sheppard et al. in review). In general, inter-tree variability is not uncommon in dendrochronology, even for ring width. Although tree growth is regulated by large-scale external factors such as climate and disturbances that affect all trees of a stand (Cook 1987), tree growth is also controlled by small-scale disturbances that affect one or just a few trees (Abrams et al. 2001) as well as by micro-site qualities such as nutrient availability or mycorrhizal populations, which can vary in forest soils at the scale of meters (Jackson and Caldwell 1993; Bruns 1995; Sheppard et al. 2001).

In dendrochemistry specifically, inter-tree variability in rings can be high, with trees within $200 \mathrm{~m}$ of each other displaying different elemental concentration patterns (Watmough and Hutchinson 2003). High inter-tree dendrochemical variability has been attributed to variable micro-site quality (McClenahan et al. 1989). In this study, the two trees that show a ring $\mathrm{P}$ response are located in an alluvial plain where pre-eruption soils eroded from upslope have been re-deposited. The two trees that did not show a ring $\mathrm{P}$ response are located on steep hillslopes. Soil allophane and other minerals such as oxides and oxyhydroxides that adsorb S and P (Gebhardt and Coleman 1974a, 1974b; Peña and Siebe 2006) are formed at depth from the weathering products of tephra. When these minerals are re-deposited on the ground surface, they weather and lose their attached nutrients. The newly available $\mathrm{S}$ and $\mathrm{P}$ nutrients are then leached to the subsoil again where they are available for plant uptake until a new allophane-rich layer develops. This new source of nutrients at the surface could be a long-term (decades) source of available $\mathrm{S}$ and $\mathrm{P}$, potentially explaining the long-term increases in ring $\mathrm{S}$ and $\mathrm{P}$ after the eruption. This might also explain in part the temporal co-variance of $\mathrm{S}$ and $\mathrm{P}$ in tree rings. 
In applications of dendrochemistry where the objective is to date a specific event that alters the environment, the fact that some trees do not show dendrochemical responses to the event is not fatal to the use of dendrochemistry. Finding multiple (at least two) trees with synchronous dendrochemical changes could be enough to fulfill that objective, even if other trees do not show the same changes. In this study, tree PAA02 shows strong dendrochemical responses to the eruption. The fact that at least one other tree (PAA01) shows at least moderate dendrochemical changes in ring $\mathrm{S}$ and $\mathrm{P}$ is helpful replication. It is curious bio-ecologically that other trees do not show strong dendrochemical changes in ring $\mathrm{S}$ and $\mathrm{P}$, but inter-tree variability is not otherwise detrimental to the objective of dating the eruption of Parícutin. This differs from other applications of dendrochemistry where the objective might be to reconstruct long-term chemical changes in the environment, in which case inter-tree variability could damp a composite chemical chronology to the point of not being able to identify environmental changes through time.

\section{Multiple Dendrochronological Responses to Parícutin}

Ring-width responses to the eruption of Parícutin illustrate the potential ambiguity with using only ring width to date cinder-cone eruptions. Had the date of the eruption not been known, a conclusion from ring width alone could have been an eruption starting in 1970 and ending in 1974, which was actually an outbreak of defoliation by insects. Interpreting ring-width changes alone as evidence for a cinder-cone eruption is potentially risky given that other forest disturbance processes such as fire (Mutch and Swetnam 1995), insect defoliation (Swetnam and Lynch 1993), extreme weather (Sheppard et al. 2005), and earthquakes (Sheppard and Jacoby 1989) can cause similar ring-width changes.

Combining multiple tree-ring characteristics of width, anatomy, and chemistry would be safer than depending on any one characteristic alone (Frelich et al. 1989). For example in dendrovolcanology, ring width and anatomy reflect injury to trees, while ring chemistry reflects changes in the chemical environment of trees. In this research, the (1) decrease in ring widths, (2) increase in inter-annual variability in width, (3) presence of traumatic resin ducts and false rings, and (4) longterm increases in ring $\mathrm{S}$ and $\mathrm{P}$, all beginning at 1943, combine to lead to the correct conclusion of 1943 as the start date for the eruption.

\section{Soil Geochemistry Regulation of Dendrochemistry}

Given that soil properties influence the chemistry of tree tissues (McClenahan and Vimmerstedt 1993), it is appropriate to consider soil geochemistry regulation of dendrochemistry. Three testable hypotheses exist for future work. One, the eruption might have caused indirect chemical changes in the soil, such as changes in $\mathrm{pH}$, that could release pre-existing $\mathrm{S}$ and $\mathrm{P}$ and thereby provide available forms (sulfate and orthophosphate) for plant uptake. Soil $\mathrm{P}$ availability is highest between $\mathrm{pH} \mathrm{6-7,} \mathrm{but} \mathrm{P}$ commonly binds with iron and aluminum at lower $\mathrm{pH}$ and with calcium at higher $\mathrm{pH}$ (Brady 1974). Changing $\mathrm{pH}$ can change the phases in which the $\mathrm{P}$ and $\mathrm{S}$ are bound, allowing a brief "window" of mobility. Additionally, allophane or aluminum and iron oxides that might be sequestering $\mathrm{S}$ and $\mathrm{P}$ could have undergone anion exchange, thereby releasing S and P (Brady 1974). This hypothesis might explain in part the temporal co-variance of $\mathrm{S}$ and $P$ in tree rings.

A second hypothesis is that $\mathrm{S}$ and $\mathrm{P}$ adhering to tephra surfaces or as gaseous aerosols might be delivered directly to the soil surface during the eruption. This is plausible, especially for areas close to an erupting volcano (Felitsyn and Kirianov 2002), but it is not likely at Parícutin because it does not adequately explain the trends in tree-ring chemistry. The long term increases for ring $\mathrm{S}$ and $\mathrm{P}$ after the eruption would be hard to explain with this hypothesis, as tephra and aerosol $\mathrm{S}$ and $\mathrm{P}$ should decrease, not increase, over time since the eruption.

A third hypothesis is that $\mathrm{S}$ and $\mathrm{P}$ might become more available as a result of weathering of tephra. This is also unlikely at Parícutin because of 
the immediate response of high ring $\mathrm{S}$ and/or $\mathrm{P}$ during the first year of the eruption. It is doubtful that $\mathrm{P}$ could weather from the tephra and alter its availability forms in such a short time. Parícutin tephra still appears quite fresh and unweathered at the ground surface.

\section{Usefulness of Dendrochemistry for Dating Volcanic Eruptions}

Dendrochemistry might be useful for confirming or improving the precision of dating of past eruptions that have been dated with other methods. Several examples of eruptions exist where old living trees, dead trees, and/or archaeological wood can be found from areas that received tephra. A prominent example in the US is Sunset Crater of northern Arizona, dated to the late A.D. 1000s \pm 40 years using paleomagnetism and ring-width dendrochronology (Smiley 1958; Elson et al. 2002). Improved precision of dating of Sunset Crater could result in better understanding its eruption sequences and/or anthropological responses to its eruption. This dendrochemistry technique has been tested only on a basaltic cinder cone eruption, so its applicability to dating eruptions of other volcano types and geochemistry is not yet known, but various past examples could be tested.

\section{CONCLUSIONS}

This Parícutin case study adds to the growing body of research using dendrochemistry to study volcanic eruptions. With further development and testing (Pearson et al. 2006), the combined use of dendrochronology and dendrochemistry could improve the analysis of eruptions of the past few centuries to perhaps a millennium or two.

\section{ACKNOWLEDGMENTS}

The Comunidad Indígena de San Juan Nuevo Parangaricutiro provided access to and guide services on their forestland around Parícutin. Víctor Peña, Cristina Siebe, Wendell Duffield, Peter Pilles, Jeffrey Dean, Jeri DeYoung, and Lee Siebert assisted this research. Review comments of previous versions of this manuscript were helpful.
This research was supported by grants from the National Science Foundation (0409117, 0409190, 0409149, 0504015) and the National Park Service (P7470-02-0040); opinions, findings, and conclusions or recommendations expressed in this material are those of the authors and do not reflect the views of the granting agencies.

\section{REFERENCES CITED}

Abrams, M. F., C. S. Copenheaver, B. S. Black, and S. van de Gevel, 2001. Dendroecology and climatic impacts for a relict, old-growth, bog forest in the Ridge and Valley Province of central Pennsylvania, USA. Canadian Journal of Botany 79: 58-69.

Baes III, C. F., and S. B. McLaughlin, 1984. Trace elements in tree rings: Evidence of recent and historical air pollution. Science 224:494-497.

Bindler, R., I. Renberg, J. Klaminder, and O. Emteryd, 2004. Tree rings as $\mathrm{Pb}$ pollution archives? A comparison of ${ }^{206} \mathrm{~Pb} /{ }^{207} \mathrm{~Pb}$ isotope ratios in pine and other environmental media. Science of the Total Environment 319:173-183.

Biondi, F., I. G. Estrada, J. C. Galvilanes Ruiz, and A. E. Torres, 2003. Tree growth response to the 1913 eruption of Volcán de Fuego de Colima, Mexico. Quaternary Research 59:293-299.

Brady, N. C., 1974. The Nature and Property of Soils, $8^{\text {th }}$ Edition. Macmillan Publishing, New York.

Brownridge, J. D., 1984. The radial distribution of ${ }^{137} \mathrm{Cs}$ and ${ }^{40} \mathrm{~K}$ in tree stems. Journal of Plant Nutrition 7:887-896.

Bruns, T. D., 1995. Thoughts on the processes that maintain local species-diversity of ectomycorrhizal fungi. Plant and Soil 170:63-73.

Clynne, M. A., D. E. Champion, D. A. Trimble, J. W. Hendley, II, and P. H. Stauffer, 2000. How Old is "Cinder Cone"?Solving a Mystery in Lassen Volcanic National Park, California. US Geological Survey Fact Sheet 023-00.

Cook, E. R., 1987. The decomposition of tree-ring series for environmental studies. Tree-Ring Bulletin 47:37-59.

Cook, E. R., and K. Peters, 1981. The smoothing spline: A new approach to standardizing forest interior tree-ring width series for dendroclimatic studies. Tree-Ring Bulletin 41:45-53.

Cutter, B. E., and R. P. Guyette, 1993. Anatomical, chemical, and ecological factors affecting tree species choice in dendrochemistry studies. Journal of Environmental Quality 22:611-619.

DeWalle, D. R., J. S. Tepp, B. R. Swistock, W. E. Sharpe, and P. J. Edwards, 1999. Tree-ring cation response to experimental watershed acidification in West Virginia and Maine. Journal of Environmental Quality 28:299-309.

Douglass, A. E., 1941. Crossdating in dendrochronology. Journal of Forestry 39:825-831.

Eggler, W. A., 1945. Paricutin, 1945. Manzama 28:80-84.

Eggler, W. A., 1948. Plant communities in the vicinity of the volcano El Parícutin, Mexico, after two and a half years of eruption. Ecology 29:415-436. 
Eggler, W. A., 1967. Influence of volcanic eruptions on xylem growth patterns. Ecology 48:644-647.

Elson, M. D., M. H. Ort, S. J. Hesse, and W. Duffield, 2002. Lava, corn, and ritual in the northern Southwest. American Antiquities 67:119-135.

Farjon, A., and B. T. Styles, 1997. Pinus (Pinaceae), Flora Neotrópica, Monograph 75. New York Botanical Garden, New York.

Felitsyn, S. B., and V. Y. Kirianov, 2002. Mobility of phosphorus during the weathering of volcanic ashes. Lithology and Mineral Resources 37:275-278.

Finch, R. H., 1937. A tree-ring calendar for dating volcanic events at Cinder Cone, Lassen National Park, California. American Journal of Science 233:140-146.

Forget, E., and J. Zayed, 1995. Tree-ring analysis for monitoring pollution by metals. In Tree Rings as Indicators of Ecosystem Health, edited by T. E. Lewis, pp. 157-176. CRC Press, Boca Raton, Florida.

Frelich, L. E., J. G. Bockheim, and J. E. Leide, 1989. Historical trends in tree-ring growth and chemistry across an air-quality gradient in Wisconsin. Canadian Journal of Forest Research 19:113-121.

Fritts, H. C., 1976. Tree Rings and Climate. Academic Press, New York.

Gebhardt, H., and N. T. Coleman, 1974a. Anion adsorption by allophanic tropical soils. 2. Sulfate adsorption. Soil Science Society of America Journal 38:259-262.

Gebhardt, H., and N. T. Coleman, 1974b. Anion adsorption by allophanic tropical soils. 3. Phosphate adsorption. Soil Science Society of America Journal 38:263-266.

Guyette, R. P., and B. E. Cutter, 1994. Barium and manganese trends in tree-rings as monitors of sulfur deposition. Water Air and Soil Pollution 73:213-223.

Hagemeyer, J., 1993. Monitoring trace metal pollution with tree rings: a critical reassessment. In Plants as Biomonitors: Indicators for Heavy Metals in the Terrestrial Environment, edited by B. Markert, pp. 541-563. VCN, Weinheim, Germany.

Hagemeyer, J., A. Lülfsmann, M. Perk, and S. W. Breckle, 1992. Are there seasonal variations of trace element concentrations $(\mathrm{Cd}, \mathrm{Pb}, \mathrm{Zn})$ in wood of Fagus trees in Germany? Vegetatio 101:55-63.

Hall, G. S., D. K. Yamaguchi, and T. M. Rettberg, 1990. Multielemental analyses of tree rings by inductively coupled plasma mass spectrometry. Journal of Radioanalytical and Nuclear Chemistry Letters 146:255-265.

Häsänen, E., and B. Huttunen, 1989. Acid deposition and the element composition of pine tree rings. Chemosphere 18: 1913-1920.

Hughes, M. K., 1988. Ice-layer dating of the eruption at Santorini. Nature 335:211-212.

Hunter, M. D., C. R. Linnen, and B. C. Reynolds, 2003. Effects of endemic densities of canopy herbivores on nutrient dynamics along a gradient in elevation in the southern Appalachians. Pedobiologia 47:231-244.

Inbar, M., J. L. Hubp, and L. V. Ruiz, 1994. The geomorphological evolution of the Paricutin cone and lava flows, Mexico, 1943-1990. Geomorphology 9:57-76.
INEGI, 1997. La Producción Forestal en la Meseta Purepecha en el Estado de Michoacán. Instituto Nacional de Estadística, Geografía e Informática, Mexico.

Jackson, R. B., and M. M. Caldwell, 1993. The scale of nutrient heterogeneity around individual plants and its quantification with geostatistics. Ecology 74:612-614.

Kramer, P. J., and T. T. Kozlowski, 1979. Physiology of Woody Plants. Academic Press, Orlando, Florida.

Luhr, J. F., and T. Simkin (Editors), 1993. Paricutin: The Volcano Born in a Mexican Cornfield. Geoscience Press, Phoenix, Arizona.

McClenahen, J. R., and J. P. Vimmerstedt, 1993. Soil, climate, and atmospheric deposition relationships with elemental concentrations in annual rings of tuliptree. Journal of Environmental Quality 22:23-32.

McClenahen, J. R., J. P. Vimmerstedt, and A. J. Scherzer, 1989. Elemental concentrations in tree rings by PIXE: Statistical variability, mobility, and effects of altered soil chemistry. Canadian Journal of Forest Research 19:880-888.

Méndez, J. T., and D. C. Tovar, 1985. Impacto del ataque de Zadiprion vallicola, defoliador de los pinos, sobre el incremento de diámetro de Pinus montezumae, en la Meseta Tarasca. In Memoria de Los Simposia Nacionales de Parasitología Forestal II y III, Publicación Especial No. 46, pp. 249-255. Sociedad Mexicana de Entomología, Mexico City, Mexico.

Momoshima, N., and E. A. Bondietti, 1990. Cation binding in wood: Applications to understanding historical changes in divalent cation availability to red spruce. Canadian Journal of Forest Research 20:1840-1849.

Mutch, L. S., and T. W. Swetnam, 1995. Effects of fire severity and climate on ring-width growth of giant sequoia after burning. In Proceedings: Symposium on Fire in Wilderness and Park Management, edited by J. K. Brown, R. W. Mutch, C. W. Spoon, and R. H. Wakimoto, pp. 241-246. USDA Forest Service General Technical Report INT-320.

Noller, J. S., J. M. Sowers, and W. R. Lettis, 2000. Quaternary Geochronology, Methods and Applications. American Geophysical Union Reference Shelf 4, Washington, DC.

Orlandi, M., M. Pelfini, M. Pavan, M. Santilli, and M. P. Colombini, 2002. Heavy metals variations in some conifers in Valle d'Aosta (Western Italian Alps) from 1930 to 2000. Microchemical Journal 73:237-244.

Padilla, K. L., and K. A. Anderson, 2002. Trace element concentration in tree-rings biomonitoring centuries of environmental change. Chemosphere 49:575-585.

Pearson, C. L., 2006. Volcanic Eruptions, Tree Rings and Multielemental Chemistry: An Investigation of Dendrochemical Potential for the Absolute Dating of Past Volcanism. BAR International Series 1556, John and Erica Hedges, Oxford, England.

Pearson, C., S. W. Manning, M. Coleman, and K. Jarvis, 2005. Can tree-ring chemistry reveal absolute dates for past volcanic eruptions? Journal of Archaeological Science 32: 1265-1274.

Pearson, C., S. W. Manning, M. Coleman, and K. Jarvis, 2006. A dendrochemical study of Pinus sylvestris from Siljansfors 
Experimental Forest, central Sweden. Applied Geochemistry 21:1681-1691.

Pelfini, M., and S. Gorza, 1994. Dendrogeomorfologia applicata allo studio delle collate laviche del 1928, 1971 e 1979 sul M. Etna. Geografia Fisica e Dinamica Quaternaria 17: 207-218.

Peña, V., and C. Siebe, 2006. Site quality changes in a volcanic chronosequence at the Trans-Mexican Volcanic Belt. $18^{\text {th }}$ World Congress of Soil Science, abstract 125-12. Philadelphia, Pennsylvania.

Phipps, R. L., 1985. Collecting, Preparing, Crossdating, and Measuring Tree Increment Cores. U.S. Geological Survey Water Resources Investigations Report 85-4148.

Poulson, S. R., C. P. Chamberlain, and A. J. Friedland, 1995. Nitrogen isotope variation of tree rings as a potential indicator of environmental change. Chemical Geology 125: 307-315.

Pulido, J. S., and G. Bocco, 2003. The traditional farming system of a Mexican indigenous community: The case of Nuevo San Juan Parangaricutiro, Michoacán, Mexico. Geoderma 111:249-265.

Segerstrom, K., 1950. Erosion studies at Parícutin volcano, state of Michoacán, México. US Geological Survey Bulletin 965A:1-164.

Sheppard, P. R., P. Casals, and E. Gutiérrez, 2001. Relationships between ring-width variation and soil nutrient availability at the tree scale. Tree-Ring Research 57:105-113.

Sheppard, P. R., and G. C. Jacoby, 1989. Application of treering analysis to paleoseismology: Two case studies. Geology 17:226-229.

Sheppard, P. R., E. M. May, M. H. Ort, K. C. Anderson, and M. D. Elson, 2005. Dendrochronological responses to the 24 October 1992 tornado at Sunset Crater, northern Arizona. Canadian Journal of Forest Research 35:2911-2919.

Sheppard, P. R., M. H. Ort, K. C. Anderson, M. A. Clynne, and E. M. May, in review. Multiple dendrochronological responses to the eruption of Cinder Cone, Lassen Volcanic National Park, California. Dendrochronologia.

Siebe, C., G. Bocco, J. Sánchez, and A. Velásquez, 2003. Suelos: distribución, características y potencial de uso. In Las Enseñanzas de San Juan: Investigación Participativa Para el Manejo Integral de Recursos Naturales, compiled by A. Velázquez, A. Torres, and G. Bocco, pp. 127-163. Instituto Nacional de Ecología-SEMARNAT, Mexico City, Mexico.

Smiley, T. L., 1958. The geology and dating of Sunset Crater, Flagstaff, Arizona. In Guidebook of the Black Mesa Basin, Northeastern Arizona, edited by R. Y. Anderson, and J. W. Harshberger, pp. 186-190. New Mexico Geological Society, Socorro, New Mexico.

Smith, K. T., and W. C. Shortle, 1996. Tree biology and dendrochemistry. In Tree Rings, Environment, and Humanity, edited by J. S. Dean, D. M. Meko, and T. W. Swetnam, pp. 629-635. Radiocarbon, Tucson, Arizona.
Sokal, R. R., and F. J. Rohlf, 1981. Biometry. WH Freeman, San Francisco, California.

Swetnam, T. W., and A. M. Lynch, 1993. Multi-century, regional-scale patterns of western spruce budworm history. Ecological Monographs 63:399-424.

Tendel, J., and K. Wolf, 1988. Distribution of nutrients and trace elements in annual rings of pine trees (Pinus silvestris) as an indicator of environmental changes. Experientia 44: 975-980.

Tovar, D. C., J. T. Méndez, R. C. Bolaños, H. O. Yates, and J. E. Flores, 1995. Insectos Forestales de México. Universidad Autónoma, Chapingo, Mexico.

Trask, P. D., 1943. The Mexican volcano Parícutin. Science 98: 501-505.

Ünlü, K., P. I. Kuniholm, J. J. Chiment, and D. K. Hauck, 2005. Neutron activation analysis of absolutely-dated tree rings. Journal of Radioanalytical and Nuclear Chemistry 264: 21-27.

van Olphen, H., 1971. Amorphous clay materials. Science 171: 91-92.

Watmough, S. A., 1997. An evaluation of the use of dendrochemical analyses in environmental monitoring. Environmental Reviews 5:181-201.

Watmough, S. A., and T. C. Hutchinson, 2003. A comparison of temporal patterns in trace metal concentration in tree rings of four common European tree species adjacent to a $\mathrm{Cu}-\mathrm{Cd}$ refinery. Water Air and Soil Pollution 146:225-241.

Wilcox, R. E., 1954. Petrology of Parícutin volcano, México. U.S. Geological Survey Bulletin 965C:281-353.

Williams, H., 1945. Geologic setting of Parícutin volcano. Transactions of the American Geophysical Union 26:255-256.

Wimmer, R., 2002. Wood anatomical features in tree-rings as indicators of environmental change. Dendrochronologia 20: 21-36.

Wimmer, R., M. Grabner, G. Strumia, and P. R. Sheppard, 1999. Significance of vertical resin ducts in tree rings of spruce. In Tree-Ring Analysis: Biological, Methodological, and Environmental Aspects, edited by R. Wimmer, and R. E. Vetter, pp. 107-118. CABI Publishing, Oxon, United Kingdom.

Wood, C. A., 1980. Morphometric evolution of cinder cones. Journal of Volcanology and Geothermal Research 7:387-413.

Yamaguchi, D. K., and D. B. Lawrence, 1993. Tree-ring evidence for 1842-1843 eruptive activity at the Goat Rocks dome, Mount St. Helens, Washington. Bulletin of Volcanology 55:264-272.

Yanosky, T. M., and W. M. Kappel, 1997. Effects of solution mining of salt on wetland hydrology as inferred from tree rings. Water Resources Research 33:457-470.

Received 15 February 2008; accepted 13 July 2008. 